\title{
Kandungan Nutrisi Black garlic Hasil Pemanasan dengan Waktu Berbeda
}

\author{
(The nutrient content of Black garlic heated at different times)
}

Nelwida Nelwida, Berliana Berliana, dan Nurhayati Nurhayati*

Fakultas Peternakan Universitas Jambi, Jl. Raya Jambi - Ma. Bulian, KM 15 Mendalo Jambi 36361

*alamat kontak : nurhayati_agus@unja.ac.id

\section{Intisari}

Penelitian ini bertujuan untuk mengetahui kandungan nutrisi bawang hitam hasil pemanasan bawang putih pada suhu $60^{\circ} \mathrm{C}$ dengan waktu pemanasan yang berbeda. Penelitian ini menggunakan Rancangan Acak Lengkap (RAL) dengan perlakuan adalah lama pemanasan yaitu 0 hari (kontrol) (P0),15 hari (P1), 30 hari (P2) dan 45 hari (P3), dan diulang sebanyak 5 kali. Setiap ulangan terdiri dari 500 gram bawang putih segar. Peubah yang diamati adalah kandungan bahan kering, protein kasar, abu, lemak kasar, dan karbohidrat. Data yang diperoleh dianalisis sesuai rancangan yang digunakan dan pengaruh yang nyata dilanjutkan dengan uji Duncan. Untuk menentukan waktu terbaik digunakan uji polynomial orthogonal. Hasil analisis ragam menunjukkan bahwa pemanasan selama 15 hari nyata $(\mathrm{P}<0,05)$ meningkatkan kandungan bahan kering tetapi kembali menurun pada pemanasan selama 30 dan 45 hari. Semakin lama pemanasan maka kadar protein dan lemak black garlic nyata $(\mathrm{P}<0,05)$ meningkat sedangkan kandungan karbohidrat nyata $(\mathrm{P}<0,05)$ menurun. Hasil polynomial orthogonal menunjukkan bahwa pemasanan bawang putih pada suhu $60^{\circ} \mathrm{C}$ selama 17 hari memberikan hasil yang terbaik untuk kandungan nutrisi black garlic. Disimpulkan bahwa lama pemanasan bawang putih untuk menghasilkan kandungan nutrisi bawang hitam terbaik adalah pada suhu $60^{\circ} \mathrm{C}$ selama 17 hari.

Kata kunci : bawang putih, lama pemanasan, bawang hitam, nutrisi

\begin{abstract}
The study was done to measure the nutritional content on black garlic based on different times of heat treatment at $60^{\circ} \mathrm{C}$. The research design was complete randomized design (CRD) with 4 treatments and 5 replications. The treatments were time of heating; P0 (control, 0 day), P1 (15 days), P2 (30 days) and P3 (45 days) $500 \mathrm{~g}$ each. Parameters were moisture content, crude protein, ash, fat and carbohydrate. Data were analysed by analysis of variance, the significant effects were tested by Duncan's multiple range test. To determine the best time of heating would be tested by Polynomial orthogonal. The results showed that different times of heat treatment significantly $(\mathrm{P}<0.05)$ affect nutrition of black garlic. Fifteen days of heating significantly incease moisture content but the moisture content decreased when heating was longer such as for 30 and 45 days. Longer time of heating increased significantly $(\mathrm{P}<0.05)$ the protein and fat content of black garlic, while the carbohydrate content significantly decreased $(\mathrm{P}<0.05)$. Polynomial orthogonal test resulted that the heating of garlic at $60^{\circ} \mathrm{C}$ for 17 days gives the best nutrient content of black garlic. It was concluded that the length heating of garlic to produce the best nutrition content of black garlic was at a temperature of $60^{\circ} \mathrm{C}$ for 17 days.
\end{abstract}

Keyword; garlic, fermentation, black garlic, nutrition

\section{Pendahuluan}

Bawang putih (Allium sativum

L) adalah tanaman herba semusim berumpun yang bagian bawahnya bersiung-siung, bergabung menjadi umbi besar berwarna putih. Bawang putih mengandung senyawa fitokimia yang bermanfaat untuk ternak khususnya unggas, senyawa ini mampu meningkatkan efisiensi ransum, memperbaiki pertumbuhan dan dapat meningkatkan produksi telur. Selain itu senyawa fitokimia tersebut dapat menghambat pertumbuhan 
mikroorganisme yang merugikan dalam saluran pencernaan ayam, sehingga pemanfaatan zat makanan oleh ayam dapat optimal dan pertumbuhan akan meningkat. Kandungan bahan kimia bawang putih antara lain air $60.3 \%$, karbohidrat $28.7 \%$, protein $8.4 \%$, lemak $0.1 \%$ dan GE 138 kkal/100 gram (Sasaki et al., 2007), sedangkan menurut USDA (2010) bawang putih mengandung air $58,58 \%$, protein $6.36 \%$, total lemak $0,5 \%$, karbohidrat $33.96 \%$, serat $2.1 \%$ dan gross energi $1490 \mathrm{kkal} / 100$ gram. Bawang putih segar mengandung air $63 \%$, karbohidrat (fruktan) 28\%, senyawa organosulfur $2.3 \%$, protein $2 \%$ (Allinase), asam amino bebas (arginine) $\quad 1.2 \%$ dan serat $1.5 \%$ (Santhosa et al., 2013). Menurut Londhe (2011) Bawang putih memiliki 33 komponen sulfur, beberapa enzim,17 asam amino dan banyak mineral.Bawang putih memiliki komponen sulfur yang lebih tinggi dibandingkan dengan spesies Allium lainnya yang mengakibatkan munculnya bau khas dan berbagai efek farmakologis atau obat dari bawang putih. Pada ternak, bawang putih dapat digunakan sebagai antibotik, antioksidan dan sebagai penurun kolesterol, membantu penyerapan zatzat makanan, sebagai perangsang tumbuh (growth promotor) dan lain sebagainya, namun bawang putih juga mempunyai kelemahan yaitu rasa yang agak pedas dan bau yang menyengat, sehingga penggunaannya dalam ransum terbatas.

Salah satu cara alternatif yang dilakukan untuk menghilangkan sifat khas bawang putih tersebut adalah melalui pengolahan yaitu dengan perlakuan panas (heat treatment) yang mampu meningkatkan rasa dan menciptakan kualitas baru dari bawang putih tanpa meng-hilangkan komponen zat gizi bawang putih mentah yang dikenal dengan nama black garlic. Black garlic memiliki warna hitam, ringan karena kandungan bahan keringnya rendah dan mempunyai aroma serta rasa yang tidak terlalu menyengat (sweet-sour), hal ini disebabkan karena terjadi transformasi alliin menjadi allicin sebagai inaktivasi panas alliinase. Black garlic memiliki sifat antibakteri lebih kuat sehingga mampu menghambat pertumbuhan bakteri Gram positif dan Gram negatif penyebab kebusukan pada produk pangan olahan (Saravanan et al., 2010).

Menurut Wang et al., (2012) black garlic adalah produk pemanasan dari bawang putih yang dipemanasan/dipanaskan pada suhu $70^{\circ} \mathrm{C}$ dengan kelembaban relatif $70-80 \%$ selama 30-40 hari tanpa perlakuan tambahan apapun. Sejalan dengan pendapat Zhang et al., (2015) yang menyatakan bahwa secara umum pemanasan bawang putih menjadi black garlic menggunakan suhu $60^{\circ} \mathrm{C}$ $70^{\circ} \mathrm{C}$ dengan waktu pemanasan 30 hari. Jika suhu pemanasan kurang dari $60^{\circ} \mathrm{C}$, black garlic yang dihasilkan akan memiliki kualitas yang tidak baik, dengan kelembaban tinggi pada permukaan dalam, sedangkan, jika suhu pemanasan lebih dari $70^{\circ} \mathrm{C}$ maka black garlic terlihat keriput dengan kenampakan yang terbakar, tekstur 
sangat keras dan bau busuk yang menyengat. Selama proses pemanasan berlangsung, zat-zat yang terdapat didalam bawang putih segar tidak akan rusak karena dibungkus dengan menggunakan allumunium foil (Lee et al., 2009).

Berdasarkan pertimbanganpertimbangan diatas maka dilakukan penelitian tentang pengaruh lama waktu pemanasan bawang putih (allium sativum L) terhadap kualitas nutrisi black garlic.

\section{Materi Dan Metode}

Penelitian ini dilakukan di Laboratorium Terpadu Fakultas Peternakan Universitas Jambi menggunakan bawang putih yang diperoleh di pasar lokal Jambi. Peralatan yang digunakan antara lain magicom kapasitas 2.5 liter, aluminium foil, penggiling, oven, timbangan dan peralatan untuk analisis proksimat.

\section{Pembuatan bawang hitam}

Proses pembuatan bawang hitam atau black garlic adalah sebagai berikut yaitu

1. Bawang putih yang ada disortir dan diseleksi dari yang sudah terkelupas kulitnya dan tidak busuk serta memiliki ukuran yang relatif sama dengan tujuan agar pada saat pemanasan memperoleh panas yang merata, pematangan juga serentak.

2. Setelah itu bawang putih dibungkus dengan aluminium foil satu persatu dan masukkan kedalam magicom yang sudah diatur panasnya berkisar $60^{\circ} \mathrm{C}$ satu persatu sehingga penuh.
3. Nyalakan magicom sesuai perlakuan yaitu 15, 30 dan 45 hari. Perlakuan kontrol (0 hari) yaitu tanpa pemanasan. Pemanenan dilakukan sesuai dengan perlakuan lama pemanasan.

4. Bawang hitam yang dipanen dikeluarkan dari Magicom, dinginkan, dilepas aluminium foil lalu ditepung untuk dianalisa guna mengukur kandungan bahan kering, protein kasar, abu, lemak kasar dan karbohidrat.

Penelitian ini menggunakan Rancangan Acak Lengkap dengan 4 perlakuan yaitu lama pemanasan $(0$, 15, 30, dan 45 hari) dan tiap perlakuan diulang sebangak 5 kali. Peubah yang diamati dalam penelitian ini adalah kandungan bahan kering, protein kasar, karbohidrat, abu dan lemak kasar. Data yang dihimpun di analisis sesuai rancangan yang digunakan, dan pengaruh perlakuan terhadap peubah yang diamati dilanjutkan dengan uji Duncan. Untuk menentukan lama pemanasan terbaik digunakan uji polinomial orthogonal (Steel dan Torrie, 1993).

\section{Hasil Dan Pembahasan Karakteristik black garlic}

Karakteristik fisik black garlic yang didperoleh dalam penelitian ini dapat dilihat pada Tabel 1. Dari Tabel 1 terlihat bahwa terjadi beberapa perubahan pada bawang putih selama proses pemanasan. Umumnya, pemanasan biasanya digunakan untuk meningkatkan kualitas bahan makanan, proses pemanasan akan mempengaruhi warna, tekstur dan 
rasa, selain itu dapat juga untuk meningkatkan kandungan senyawa aktif di dalamnya. Menurut Zhang et al., (2015) selama proses pemanasan akan terjadinya perubahan fisikokimia seperti warna tekstur dan rasa serta perubahan kandungan nutrisi bawang putih. Saat bawang putih segar dipanaskan maka teksturnya akan lengket seperti jelly, rasanya menjadi manis dan asam, dan warna berubah menjadi coklat kehitaman. Intensitas warna kecoklatan akan semakin meningkat sejalan dengan lamanya waktu pemanasan (Bae et al., 2014). Produk black garlic yang baik harus Tabel 1. Hasil Pemeriksaan Karakteristik Fisik Bawang Hitam

\begin{tabular}{lll}
\hline Perlakuan & Karakteristik fisik & Hasil pengamatan \\
\hline Pemanasan 15 hari & Bentuk & Padat, lunak agak basah \\
& Warna & Coklat muda \\
& Aroma & Khas bawang \\
Rasa & Tidak berasa \\
\hline Pemanasan 30 hari & Bentuk & Padat, kenyal \\
& Warna & Coklat tua \\
& Aroma & Tidak beraroma \\
& Rasa & Manis sedikit asam \\
\hline & Bentuk & Padat Kenyal \\
& Warna & Coklat Kehitaman \\
\hline
\end{tabular}

Secara umum, pembuatan black garlic di Indonesia hanya dengan cara memanaskan bawang putih selama 15-20 hari dan dapat menghasilkan black garlic dengan tekstur yang lembut dan rasanya manis serta tidak beraroma menyengat seperti pada bawang putih segar. Bawang putih dengan lama pemanasan 30 hari atau lebih akan menghasilkan black garlic dengan warna yang sangat hitam, memenuhi beberapa kriteria diantaranya warna hitam, tekstur lembut, rasa yang manis dan tidak mengeluarkan aroma menyengat seperti bawang putih segar. Sesuai dengan pendapat Amagase (2001) yang menyatakan bahwa senyawa allin yang terdapat pada bawang putih bersifat tidak stabil dan mudah menguap. Transformasi allin menjadi allicin akan mengakibatkan rasa dan aroma pada black garlic menjadi tidak terlalu menyengat seperti bawang putih segar (Hernawan dan Setyawan, 2003). 
keringnya akan menghilang. Selain itu aroma tajam yang terdapat didalam bawang putih segar pun akan menghilang setelah proses pemanasan. Lebih lanjut dijelaskan oleh Nursten (2005) bahwa perubahan warna akibat perlakuan panas biasanya disebabkan oleh reaksi Maillard, yang dikenal sebagai reaksi pencoklatan nonenzimatik. Lebih lanjut Bae et al., (2014) menjelaskan banwa proses pemanasan dapat menyebabkan reaksi pencoklatan non enzimatis seperti reaksi Maillard, karamelisasi dan oksidasi fenol dimana sejumlah reaksireaksi tersebut berkaitan dengan pembentukan senyawa yang memiliki sifat antioksidan yang kuat. Menurut Yusmarini dan Pato (2004), pemanasan dengan waktu yang lama dapat menyebabkan kerusakan pada karbohidrat yaitu terjadinya reaksi browning non enzimatik (reaksi Maillard) dan karamelisasi. Reaksi Maillard terjadi karena adanya reaksi antara gugus amino protein dengan gugus karboksil gula pereduksi yang menghasilkan bahan berwarna coklat, sedangkan karamelisasi terjadi karena adanya reaksi antara gula dan panas. Oleh karena itu, hasil pemanasan bawang putih menjadi black garlic akan Tabel 2. Komposisi nutrisi tepung black

\begin{tabular}{llllll}
\multicolumn{1}{c}{ Hari } & BK & PK & LK & Abu & KH \\
\hline P0 (0) & $63,67^{\mathrm{a}}$ & $16,66^{\mathrm{b}}$ & $1,63^{\mathrm{b}}$ & $5,99^{\mathrm{b}}$ & $27,52^{\mathrm{a}}$ \\
P1(15) & $69,74^{\mathrm{b}}$ & $15,81^{\mathrm{b}}$ & $4,41^{\mathrm{a}}$ & $3,82^{\mathrm{c}}$ & $22,98^{\mathrm{bc}}$ \\
P2(30) & $66,13^{\mathrm{a}}$ & $18.37^{\mathrm{b}}$ & $3,15^{\mathrm{a}}$ & $5,30^{\mathrm{b}}$ & $24,85^{\mathrm{ab}}$ \\
P3(45) & $65,44^{\mathrm{a}}$ & $26.45^{\mathrm{a}}$ & $4,38^{\mathrm{a}}$ & $8,77^{\mathrm{a}}$ & $20,89^{\mathrm{c}}$ \\
\hline
\end{tabular}

\section{Kandungan Bahan Kering}

\section{Hasil analisis ragam menun- jukkan bahwa lama waktu pemanasan}

menghasilkan black garlic yang berwarna cokelat gelap dan rasa manis segar dikarena-kan bawang putih mengalami reaksi Maillard (Choi et al., 2014), lebih jauh dijelaskan bahwa reaksi Maillard atau reaksi pencoklatan non enzimatis terjadi karena adanya reaksi antara gula pereduksi dengan gugus amin bebas dari asam amino atau protein. Didukung oleh Winarno (2004) yang menyatakan bahwa reaksi Maillard akan menghasilkan warna coklat pada bahan yang dipanaskan, reaksi Maillard merupakan reaksi antara karbohidrat khususnya gula pereduksi dengan gugus amina primer yang menghasilkan bahan berwarna coklat yang disebut melanoidin. Produk akhir dari reaksi Maillard untuk setiap jalur reaksi adalah melanoidin. Melanoidin merupakan senyawa yang bertanggung jawab terhadap timbulnya warna cokelat pada makanan (Zhuang dan Sun, 2011).

\section{Kandungan Nutrisi Black Garlic}

Rataan hasil analisa kandungan nutrisi tepung bawang putih dan black garlic yang diperoleh dalam penelitian ini dapat dilihat pada Tabel 2.

nyata $\quad(\mathrm{P}<0,05) \quad$ mempengaruhi kandungan bahan kering black garlic. Uji Duncan menunjukkan bahwa 
kandungan bahan kering tertinggi terdapat pada pemanasan selama 15 hari (P1) yang nyata lebih tinggi dibandingkan perlakuan P2, P3 dan P4. Kandungan bahan kering terendah atau kadar air tertinggi terjadi pada pemanasan selama 0 hari. Hal ini dapat dipahami karena perlakuan P0 tanpa terjadi pemanasan sehingga tidak banyak penguapan air dan bahan organik yang mudah menguap. Akibatnya air masih tertahan didalam bahan dan bahan kering jadi berkurang. Menurut Winarno (2004) dan Fitriani (2008), semakin lama waktu pemanasan akan menyebabkan penguapan air lebih banyak karena peningkatan panas akan semakin meningkatkan kemampuan bahan untuk melepaskan air dari permukaannya dan akibatnya kandungan bahan kering yang dihasilkan semakin berkurang. Semakin banyak energi panas yang dikeluarkan oleh media yang digunakan sebagai pemanas selama pemanasan makin besar penguapan yang terjadi (Hikmah et al., 2009). Sejalan dengan Hasil penelitian Zhang et al., (2015) juga menunjukkan bahwa kandungan bahan kering dari black garlic menurun sejalan dengan meningkatnya suhu.

Kandungan bahan kering yang diperoleh dari penelitian ini berkisar dari yang terendah sampai yang tertinggi yaitu P1(69,74\%), P2 (66.13\%), P3 (65.44\%) dan P0 (63.67\%). Kandungan bahan kering lebih dari $60 \%$ berarti kadar air yang terkandung kurang dari $40 \%$ dan keadaan ini tetap menyebabkan black garlic yang dihasilkan masih bertekstur lembut. Sesuai dengan pendapat Lei et al., (2012) yang menyatakan bahwa bila kandungan bahan kering black garlic di bawah 30\% maka black garlic yang dihasilkan akan memiliki tekstur lebih kering dan elastisitasnya tidak baik, sedangkan bila bila kandungan bahan kering 30\%-50\% maka black garlic memiliki tekstur lembut dan elastis, sedangkan bila kandungan bahan kering black garlic di atas 50\% black garlic yang dihasilkan akan bertekstur lembut dan basah. Menurut Husna et al., (2017) kandungan bahan kering pada bawang putih segar berkisar antara 60.9-67.8\%. Uji polinomial orthogonal menghasilkan persamaan untuk kandungan bahan kering Black garlic yaitu 35,71 - 0,3499 hari + 0,007523 hari $^{2}$ yang bermakna bahwa kandungan bahan kering black garlic akan semakin menurun dengan meningkatnya lama pemanasan.

\section{Protein Kasar}

Hasil analisis menunjukkan bahwa lama waktu pemanasan nyata $(\mathrm{P}<0.05) \quad$ dapat meningkatkan kandungan protein black garlic, dengan kandungan protein yang tertinggi terdapat pada lama waktu pemanasan 45 hari. Hasil uji Duncan menunjukkan bahwa kandungan protein pada $\mathrm{P} 1<\mathrm{P} 0<\mathrm{P} 2<\mathrm{P} 3$. Hal ini diduga disebabkan karena kandungan bahan kering pada bahan semakin lama proses pemanasan akan semakin menurun sehingga menyebabkan komponen bahan organik yang tidak mudah menguap termasuk didalamnya adalah protein pada bahan menjadi meningkat. Selain itu 
juga disebabkan oleh peningkatan sintesis protein melalui pemanasan. Hal ini didukung oleh Paggara (2008), yang menyatakan bahwa turunnya kandungan bahan kering dengan semakin lama waktu pemanasan akan meningkatkan persentase kadar protein di dalam bahan. Sejalan dengan pendapat Adawyah (2007), bahwa kandungan bahan kering yang mengalami penurunan akan mengakibatkan kandungan protein didalam bahan mengalami peningkatan.

Peningkatan kadar protein akan mempengaruhi warna pada bahan karena dapat menyebabkan reaksi Maillard, yaitu reaksi antara karbohidrat, khususnya gula pereduksi dengan gugus amina primer. Hasil reaksi tersebut menghasilkan produk berwarna coklat atau disebut juga sebagai reaksi browning (Winarno, 2004). Penggunaan panas dalam pengolahan bahan pangan dapat menurunkan persentase kandungan bahan kering yang mengakibatkan persentase kadar protein meningkat. Berarti semakin kering suatu bahan maka semakin tinggi kadar proteinnya. Menurut Corzo-Martinez et al., (2007) bahwa selama proses pemanasan senyawa allin (asam amino) yang tidak stabil akan dikonversi menjadi senyawa yang lebih stabil yaitu S-Alylcysteine (Allicin). Choi et al., (2008) juga melaporkan bahwa kandungan allicin/thio-sulfinates bawang putih segar $77 \mu \mathrm{mol} / \mathrm{g}$ sedangkan pada black garlic $278 \mu \mathrm{mol} / \mathrm{g}$. Menurut Sasaki et al., (2007) kandungan beberapa asam amino akan meningkat di dalam black garlic khususnya phenylalanine, tirosin, leusin, isoleusin, metionin, valin, alanine, glysin, asam glutamik dan asam aspartate. Sejalan dengan pendapat Queiroz et al., (2009) yang menyata-kan bahwa black garlic memiliki kandungan protein serta komponen yang mengandung sulfur yang tinggi. Uji polinomial orthogonal menghasilkan persamaan untuk kandungan protein kasar Black garlic yaitu 16,76 - 0,2344 hari + 0,009918 hari $^{2}$ yang bermakna bahwa kandungan protein kasar black garlic akan semakin meningkat dengan meningkatnya lama pemanasan.

\section{Kadar Lemak}

$$
\text { Hasil analisis ragam }
$$

menunjukkan bahwa lama waktu pemanasan nyata $\quad(\mathrm{P}<0.05)$ mempengaruhi kadar lemak pada black garlic. Hasil uji Duncan menunjukkan bahwa $\mathrm{P} 0<\mathrm{P} 2<\mathrm{P} 3<\mathrm{P} 1$, tetapi antara P1, P2 dan P3 tidak bebeda. sehingga diperoleh kandungan lemak tertinggi terdapat pada lama waktu pemanasan 15 hari. Hal ini diduga karena degradasi bahan organik yang terjadi selama proses pemanasan akan menyebabkan bertambahnya asam lemak esensial pada bentuk asam asetat, asam propionat, dan asam butirat. Dalam proses pemanasan/pemanasan asam lemak berfungsi sebagai pemasok energi untuk meningkatkan sintesis lemak.

Selain itu juga diduga bawa hidrolisis asam lemak dapat menyebabkan terjadinya peningkatan kandungan lemak pada black garlic. Ini didukung oleh Sasaki et al., (2007) yang menyatakan bahwa terjadi 
peningkatan kandungan lemak dari 0.1 $\%$ pada bawang putih segar menjadi $0.3 \%$ pada black garlic. Menurut Zuhra et al. (2012), peningkatan kadar lemak bahan dapat disebabkan oleh penurunan kandungan bahan kering sehingga persentase kadar lemak meningkat. Lemak merupakan suatu senyawa yang terbentuk sebagai hasil dari reaksi esterifikasi antara gliserol dengan asam lemak. Pemberian panas yang tinggi pada lemak akan mengakibatkan terputusnya ikatanikatan rangkap pada lemak, sehingga lemak tersebut akan terdekomposisi menjadi gliserol dan asam lemak. Sejalan dengan pendapat Yuniarti (2007), yang menyatakan bahwa dengan lamanya waktu pemanasan akan menyebabkan kandungan lemak yang ada pada bahan juga semakin meningkat dan kandungan air yang semakin menurun. Secara keseluruhan menurut Muchtadi dan Ayustaningwarno (2010), menyimpulkan bahwa dengan berkurangnya kandungan bahan kering bahan pangan akan meningkatkan kandungan senyawasenyawa seperti karbohidrat, protein dan mineral dalam konsentrasi yang lebih tinggi. Uji polinomial orthogonal menghasilkan persamaan untuk kandungan lemak kasar Black garlic yaitu 1,954 + 0,01242 hari - 0,001723 hari $^{2}$ yang bermakna bahwa kandungan lemak kasar black garlic akan meningkat selama pemanasan 15 hari kemudian menurun dengan meningkatnya lama pemanasan.

\section{Kadar abu}

$\begin{array}{ccc}\text { Hasil } & \text { analisis } & \text { ragam } \\ \text { menunjukkan } & \text { bahwa lama } & \text { waktu }\end{array}$ pemanasan nyata $(\mathrm{P}<0.05) \quad$ meningkatkan kadar abu pada black garlic. Kadar abu tertinggi diperoleh pada lama pemanasan 45 hari. Uji Duncan menunjukkan bahwa P1 < P2 < P0 < P3, namun antara P0 dan P2 tidak berbeda. Peningkatan kadar abu dengan semakin lama waktu pemanasan berbanding terbalik dengan kandungan bahan kering yang semakin menurun. Kadar abu tertinggi diperoleh pada pemanasan 45 hari. Uji polinomial orthogonal menghasilkan persamaan untuk kandungan abu Black garlic yaitu 5,905 - 0,2167 hari + 0,006273 hari $^{2}$ yang artinya kandungan abu atau bahan an organik pada black garlic akan semakin meningkat dengan meningkatnya lama pemanasan.

Dari hasil penelitian ini terlihat bahwa semakin rendah kandungan bahan kering bahan maka persentase kadar mineral atau abu akan semakin tinggi, hal ini diduga karena semakin lama waktu pemanasan akan semakin meningkatkan jumlah bahan organik yang terdegradasi. Menurut Asrawaty (2011) peningkatan kadar abu terjadi karena semakin lama waktu pemanasan maka akan semakin banyak air yang teruapkan. Menurut Hadipernata et al.,(2006) selama proses pemanasan terjadi penguraian komponen ikatan molekul air (H2O) dan meningkatkan kandungan gula, lemak, mineral dan protein sehingga meningkatkan kadar abu. Hasil penelitian Sasaki et al., (2007) melaporkan bahwa bawang putih segar tidak terdeteksi adanya kadar abu, sedangkan pada black garlic terdapat kadar abu sebesar 2.1\%. Hasil 
uji polinomial orthogonal memperlihatkan persamaan untuk kandungan bahan kering abu Black garlic yaitu 35,71 - 0,3499 hari $+0,007523$ hari $^{2}$ yang bermakna bahwa kandungan bahan kering black garlic akan semakin menurun dengan meningkatnya lama pemanasan.

\section{Karbohidrat}

Hasil analisis ragam menunjukkan bahwa lama waktu pemanasan nyata $(\mathrm{P}<0.05)$ menurunkan kandungan karbohidrat black garlic. Uji lanjut Duncan menunjukkan bahwa P3 $<$ P1 $<$ P2 < P0 sedangkan antara P0, P1 dan P2 tidak berbeda. Hasil ini menunjukkan bahwa kandungan karbohidrat yang terrendah terdapat pada lama waktu pemanasan 45 hari. Hal ini disebabkan karena proses pemanasan/ pemanasan ini terjadi secara enzimatis sehingga mampu mengubah karbohidrat menjadi gula . Sejalan dengan hasil penelitian Sasaki et al., (2007) yang melaporkan bahwa terjadi peningkatan kadar karbohidrat pada black garlic jika dibanding dengan bawang putih segar. Peningkatan persentase karbohidrat dengan semakin lama waktu pemanasan disebabkan karena selama proses pemanasan terjadi penguraian komponen ikatan molekul air (H2O) yang menyebabkan peningkatan kandungan karbohidrat karena molekul air membentuk hidrat dengan molekul-molekul lain yang mengandung atom-atom $\mathrm{O}$ dan $\mathrm{N}$ seperti karbohidrat (Hadipernata, 2006). Selain itu, peningkatan kadar karbohidrat juga mempengaruhi peningkatan total padatan terlarut di mana semakin lama pemanasan maka gula sebagai komponen karbohidrat semakin larut sehingga total padatan terlarut meningkat (Buckle et al., 2009). Karbohidrat dapat memperbaiki rasa black garlic menjadi manis karena adanya sukrosa dan warna coklat kehitaman karena terjadinya reaksi Maillard antara gula dan asam amino pada saat dipanaskan. Lebih lanjut dinyatakan oleh Choi et al., (2014) bahwa kandungan gula (glukosa, fruktosa, sukrosa, dan maltosa) pada black garlic meningkat dibanding bawang putih segar, peningkatan kadar gula ini berhubungan dengan rasa manis pada black garlic.

Kandungan gula pereduksi pada proses pembuatan bawang hitam dipengaruhi oleh dua faktor, yang pertama adalah terjadinya reaksi hidrolisis polisakarida menjadi gula pere-duksi akan menyebabkan kadar gula pereduksi meningkat. Sedang faktor kedua adalah ter-jadinya reaksi Maillard yang menyebabkan penurunan kadar gula pereduksi. Penurunan kadar gula pereduksi sampai hari ke-45 disebabkan karena reaksi hidrolisis polisakarida berlangsung lebih cepat dibandingkan reaksi Maillard (Zhang et al.,2014). Hasil uji polinomial orthogonal untuk pendugaan kandungan karbohidrat kering Black garlic yaitu 26,91 - 0,1492 hari $+0,006433$ hari $^{2}$ yang artinya bahwa akan terjadi penurunan kandungan karbohidrat black garlic dengan meningkatnya lama pemanasan. 


\section{Kesimpulan}

Dari hasil dan pembahasan disimpulkan bahwa Disimpulkan bahwa lama pemanasan bawang putih untuk menghasilkan kandungan nutrisi bawang hitam terbaik adalah pada suhu $60^{\circ} \mathrm{C}$ selama 17 hari.

\section{Daftar Pustaka}

Adawyah, R. 2007. Pengolahan dan Pengawetan Ikan. Bumi Aksara. Jakarta.

Amagase, H., B.L. Petesch, H. Matsuura,S. Kasuga and Y. Itakura. 2001. Intake of garlic and its bioactive components. The Journal of nutrition,131(3);955S-962S.

Asrawaty. 2011. Pengaruh suhu dan lama pengeringan terhadap mutu tepung pandan. Jurnal KIAT edisi Juni. Universitas Alkhairaat. Palu.

Bae, S. E., S.Y. Cho, Y.D. Won, S.H. Lee and H.J. Park., 2014. Changes In S-Allylcysteine Contents and Phsicochemical Properties of Black garlic During Heat Treatment. LWT-Food Science and Technology. 55:397402.

Buckle, K.A., R.A. Edward, G.H. Fleet dan M. Wooton, 2009. Ilmu Pangan. Diterjemahkan oleh Hari Purnomo dan Adiono. UIPress, Jakarta.

Choi, J.D., J.S. Lee, J.M. Kang, S.H. Cho, J.N. Sung, H.J. Shin. 2008. Physicochemical

Characteristics of Black garlic (Allium sativum L.). J. Korean Soc. Food Sci. Nutr. 37(4):465471.
Choi, I.S., H.S. Cha and Y.S. Lee. 2014. Physicochemical and antioxidant properties of black garlic. Molecules, 19:1681116823. doi:10.3390/molecules19101681 1.

Corzo-Martinez, M., Corzo, N., and Villamiel, M. 2007. Biological properties of unions and garlic. Trends Food Sci. Technol, 18:609-625.

Fitriani, S. 2008. Pengaruh suhu dan lama pengeringan terhadap beberapa mutu manisan belimbing wuluh (Averrhoabellimbi L.). Jurnal SAGU, 7(1);32 - 37.

Hadipernata, M. R., Rachmat dan Widaningrum.2006. Pengaruh suhu pengeringan pada teknologi Far Infrared (FIR) terhadap mutu jamur merang kering (Volvariella volvociae). Buletin Teknologi Pascapanen Pertanian Volume 2 (2): 62-69.

Hernawan, U.E., A.D. Setyawan. 2003.Review: Senyawa Organo sulfur Bawang Putih (Allium sativum L.) dan Aktivitas Biologinya. Biofarmasi, 1(2):6576.

Hikmah, A. F., S. A. Budhiyanti dan N. Ekantari, 2009. Pengaruh Pengeringan terhadap Aktivitas Antioksidan Spirulina platensis. Prosiding Seminar Nasional Tahunan VI Hasil Penelitian Perikanan dan Kelautan. PA-04:1-11.

Husna, A., R. Khathir dan K. Siregar. 2017. Karakteristik Pengeringan 
Bawang Putih (Allium

sativum L) Menggunakan Pengering Oven. Jurnal Ilmiah Mahasiswa Pertanian Unsyiah, 2(1): 338-347.

Lee, Y. M., O.C. Gweon, Y. Seo, J. Im, M.J. Kang, M. J., Kim, and J.I. Kim. 2009. Antioxidant effect of garlic and aged black garlic in animal model of type 2 diabetes mellitus. Nutrition research and practice, 3(2);156161.DOI:10.4162/nrp.2009.3.2.15 6

Lei, F.C., G. Hao, L. Zhu, Y. Yang, and Y.L. Zhang, 2012. Study Progress on Nutritional Value and Health Effect of Black Garlic. Food Sci. Eng. 13: 429 432.

Londhe, V.P., A.T. Gavasane, S.S. Nipate. D.D. Bandawane, and P.D. Chaudhari. 2011. Role of Garlic (Allium Satioum) in Various Disease:An Overview J. of Pharmaceutical Research and Opinion, 1(4): 129-134.

Muchtadi, T. R. dan F. Ayustaningwarno. 2010. Teknologi Proses Pengolahan Pangan. Alfabeta.

Bandung.

Nursten, H., 2005. The Maillard Reaction: Chemistry Biochemistry and Implications; The Royal Society of Chemistry. Cambridge United Kingdom. pp. 2 - 4.

Paggara, H. 2008. Pengaruh lama pengeringan terhadap kadar protein ulat sagu $(R$
Furregineus). Jurnal Bionature, 9(1);55- 60.

Queiroz, Y.S., E.Y. Ishimoto, D.H.M. Bastos, G.R. Sampaio and E.A.F.S. 2009. Garlic (Allium sativum L.) and ready-to-eat garlic products: in vitro antioxidant activity. Food Chem. 115:371-374.

Santhosha, S.G., P. Jamuna and S.N. Prabhavathi. 2013. Bioactive components of garlic and their physiological role in health maintenance: a review. Food Bio sci, 3:59-74.

Saravanan, P., V. Ranya, H. Sridhar,V., Balamurugan and $S$. Umantaheswari. 2010. Antibacterial Activity of Allium sativum L., on Pathogenic Bacterial Strain. Global Veterinaria, 4(5): 519-522.

Sasaki, J.I., C. Lu, E. Machiya, M. Tanahashi and K. Hamada. 2007. Processed Black Garlic (Allium sativum) Extracts EnhanceAnti-Tumor Potency against Mouse Tumors. Medicinal and Aromatic Plant Science and Biotechnology. 1(2);278-281.

Steel, R.G.D. and J. H. Torrie. 1995. Prinsip dan Prosedur Statistika Suatu Pendekatan Biometrik. Cet. ke-4. Alih Bahasa B.Sumantri. PT Gramedia Pustaka Utama, Jakarta.

USDA. 2010. National Nutrient Database for Standard Reference of Raw Garlic. Agricultural Researce Service. 
United State Departement of Agriculture.

Wang, X., F. Jiao, Q.W. Wang, J. Wang, K. Yang, R.R. Hu, H.C. Liu, N.Y. Wang and Y.S. Wang, 2012. Aged Black garlic Extract Induces Inhibition of Gastric Cancer Cell Growth in Vitro and in Vivo. Journal of Molecular Medicine Reports. 5: 66-72.

Winarno, F.G., 2004. Kimia Pangan dan Gizi. PT. Gramedia Pustaka Utama. Jakarta.

Yuniarti, N., D. Syamssuwida dan A. Aminah. 2007. Pengaruh penurunan kandungan bahan kering terhadap perubahan fisiologi dan kandungan biokimia benih eboni (Diospyros celebica Bahk.). Jurnal Penelitian Hutan Tanaman, 5(3);191 - 198.

Yusmarini dan Pato. 2004. Teknologi Pengolahan Hasil Tanaman Pangan. Gramedia Pustaka Utama. Jakarta.
Zhang, Z., M. Lei, R. Liu, Y. Gao, M. $\mathrm{Xu}$ and $\mathrm{M}$. Zhang.2014.Evaluation of Alliin, Saccharide Contents and Antioxidant Activities of Black garlic During Thermal Processing. Journal of Food Biochemistry, 39-47.

Zhang, X., N. Li, X. Lu, P. Liu and X. Qiao. 2015. Effects of Temperature on the Quality of Black Garlic. Journal Science Food Agricultural. 96: 23662372.

Zhuang, Y., and L. Sun. 2011. Antioxidant activity of Maillard reaction products from lysineglucose model system as related to optical property and copper (II) binding ability. African Journal of Biotechnology, 10(35).

Zuhra, S. dan C. Erlina. 2012. Pengaruh kondisi operasi alat pengering semprot terhadap kualitas susu bubuk jagung. Jurnal Rekayasa Kimia dan Lingkungan. $\quad 9(1) ; 36 \quad-44$. 